\title{
Prevention of Cervical Cancer
}

\author{
Guideline of the DGGG and the DKG (S3 Level, AWMF Register Number 015/027OL, \\ December 2017) - Part 1 with Introduction, Screening and the Pathology of Cervical \\ Dysplasia
}

\section{Prävention des Zervixkarzinoms}

Leitlinie der DGGG und DKG (S3-Level, AWMF-Register-Nummer 015/027OL, Dezember 2017) - Teil 1 mit Einführung, Screening und Pathologie von zervikalen Dysplasien

\section{(우 (1) (오 $\ominus$}

Authors

Peter Hillemanns ${ }^{1}$, Klaus Friese ${ }^{2}$, Christian Dannecker ${ }^{3}$, Stefanie Klug ${ }^{4}$, Ulrike Seifert ${ }^{5}$, Thomas Iftner ${ }^{6}$, Juliane Hädicke ${ }^{6}$, Thomas Löning ${ }^{7}$, Lars Horn ${ }^{8}$, Dietmar Schmidt ${ }^{9}$, Hans Ikenberg ${ }^{10}$, Manfred Steiner ${ }^{11}$, Ulrich Freitag ${ }^{12}$, Uwe Siebert ${ }^{13,14}$, Gaby Sroczynski ${ }^{13}$, Willi Sauerbrei ${ }^{15}$, Matthias W. Beckmann ${ }^{16}$, Marion Gebhardt ${ }^{17}$, Michael Friedrich ${ }^{18}$, Karsten Münstedt ${ }^{19}$, Achim Schneider ${ }^{20}$, Andreas Kaufmann ${ }^{21}$, K. Ulrich Petry ${ }^{22}$, Axel P. A. Schäfer ${ }^{23}$, Michael Pawlita ${ }^{24}$, Joachim Weis ${ }^{25}$, Anja Mehnert ${ }^{26}$, Mathias Fehr ${ }^{27}$, Christoph Grimm ${ }^{28}$, Olaf Reich ${ }^{29}$, Marc Arbyn ${ }^{30}$, Jos Kleijnen ${ }^{31}$, Simone Wesselmann ${ }^{32}$, Monika Nothacker ${ }^{33}$, Markus Follmann ${ }^{34}$, Thomas Langer ${ }^{34}$, Matthias Jentschke ${ }^{1}$

Affiliations

1 Klinik für Frauenheilkunde und Geburtshilfe, Medizinische Hochschule Hannover, Hannover, Germany

2 Klinik Bad Trissl GmbH, Oberaudorf, Germany

3 Klinik und Poliklinik für Frauenheilkunde und Geburtshilfe, München, Germany

4 Lehrstuhl für Epidemiologie, Technische Universität München, München, Germany

5 Tumorepidemiologie, Universitäts KrebsCentrum (UCC), Universitätsklinikum Carl Gustav Carus an der Technischen Universität Dresden, Dresden, Germany

6 Institut für Medizinische Virologie und Epidemiologie der Viruskrankheiten, Universitätsklinikum Tübingen, Tübingen, Germany

7 Institut für Pathologie, Albertinen-Krankenhaus Hamburg, Hamburg, Germany

8 Institut für Pathologie, Universitätsklinikum Leipzig, Leipzig, Germany

9 Institut für Pathologie, Referenzzentrum für Gynäkopathologie, Mannheim, Germany

10 CytoMol - MVZ für Zytologie und Molekularbiologie, Frankfurt, Germany

11 Facharzt für Frauenheilkunde und Geburtshilfe, Ihringen, Germany

12 Facharzt für Frauenheilkunde und Geburtshilfe, Wismar, Germany

13 Institute of Public Health, Medical Decision Making and Health Technology Assessment, Department of Public Health, Health Services Research and Health Technology Assessment, UMIT - University for Health Sciences, Medical Informatics and Technology, Hall i. T., Austria
14 Division of Health Technology Assessment and Bioinformatics, ONCOTYROL - Center for Personalized Cancer Medicine, Innsbruck, Austria

15 Institut für Med. Biometrie und Statistik (IMBI), Universitätsklinikum Freiburg, Freiburg, Germany

16 Frauenklinik, Universitätsklinikum Erlangen, Erlangen, Germany

17 Frauenselbsthilfe nach Krebs, Forchheim, Germany

18 Klinik für Frauenheilkunde und Geburtshilfe, Helios Klinikum Krefeld, Krefeld, Germany

19 Frauenklinik, Ortenau Klinikum Offenburg-Gengenbach, Offenburg, Germany

20 Medizinisches Versorgungszentrum im FürstenbergKarree, Berlin, Germany

21 Klinik für Gynäkologie, Campus Benjamin Franklin, Charité - Universitätsmedizin Berlin, Berlin, Germany

22 Frauenklinik, Klinikum Wolfsburg, Wolfsburg, Germany

23 Facharzt für Frauenheilkunde und Geburtshilfe, Berlin, Germany

24 Deutsches Krebsforschungszentrum, Heidelberg, Germany

25 Klinik für Tumorbiologie, Klinik für Onkologische Rehabilitation - UKF Reha gGmbH, Freiburg, Germany

26 Abteilung für Medizinische Psychologie und Medizinische Soziologie, Universitätsklinikum Leipzig, Leipzig, Germany

27 Gynäkologie \& Geburtshilfe in Frauenfeld, Spital Thurgau AG, Frauenfeld, Switzerland

28 Privatklinik Döbling, Wien, Austria

29 Privatklinik Graz Ragnitz, Graz, Austria

30 Cancer Center, Sciensano, Brüssel, Belgium

31 Kleijnen Systematic Reviews Ltd, York, United Kingdom 


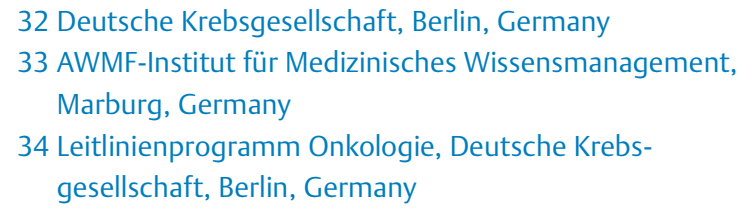

Key words

cervical cancer, cervical intraepithelial neoplasia (CIN), cervical precancerous condition, HPV

\author{
Schlüsselwörter \\ $\begin{array}{ll}\text { received } & 21.8 .2018 \\ \text { revised } & 3.12 .2018 \\ \text { accepted } & 8.12 .2018\end{array}$
}

Zervixkarzinom, zervikale intraepitheliale Neoplasie (CIN), zervikale Präkanzerosen, HPV

Bibliography

DOI https://doi.org/10.1055/a-0818-5440

Geburtsh Frauenheilk 2019; 79: 148-159 @ Georg Thieme

Verlag KG Stuttgart · New York | ISSN 0016-5751

Correspondence

Univ.-Prof. Dr. Peter Hillemanns

Klinik für Frauenheilkunde und Geburtshilfe,

Medizinische Hochschule Hannover

Carl-Neuberg-Straße 1, 30625 Hannover, Germany

Hillemanns.Peter@mh-hannover.de

$\Theta$

Deutsche Version unter:

https://doi.org/10.1055/a-0818-5440

\section{ABSTRACT}

Aims Annual opportunistic screening for cervical carcinoma has been carried out in Germany since 1971. The creation of this S3 guideline meets an important need, outlined in the National Cancer Plan, with regard to screening for cervical cancer, as the guideline aims to provide important information and support for planned organized screening for cervical cancer in Germany.

Methods With the financial support of German Cancer Aid, 21 professional societies developed evidence-based statements and recommendations (classified using the GRADE system) for the screening, management and treatment of pre- cancerous conditions of the cervix. Two independent scientific institutes compiled systematic reviews for this guideline.

Recommendations The first part of this short summary presents the pathological basis and considers various questions related to screening for cervical cancer. As also reported in earlier reviews, the meta-analysis by Kleijnen Systematic Reviews showed that HPV-based screening offers better protection against invasive cervical cancer compared to cytologybased screening. The authors of this guideline therefore recommend - in accordance with the guideline of the Joint $\mathrm{Na}$ tional Committee of Germany (Gemeinsamer Bundesauschuss, G-BA) - that women aged 35 and above should be examined at regular intervals (at least every 3 years) and undergo HPV-based screening. Co-testing can also be carried out. Women between the ages of 20 and 35 should have cytological screening every 2 years.

\section{ZUSAMMENFASSUNG}

Ziele Seit 1971 erfolgt in Deutschland die jährliche, opportunistische Früherkennungsuntersuchung des Zervixkarzinoms. Durch die Etablierung dieser S3-Leitlinie wird zum einen eine wichtige Forderung des Nationalen Krebsplans zum Zervixkarzinom-Screening erfüllt. Zum anderen kann die S3-Leitlinie wesentliche Informationen und Hilfestellungen für das geplante organisierte Zervixkarzinomscreening in Deutschland geben.

Methoden Mit finanzieller Unterstützung durch die Deutsche Krebshilfe wurden durch 21 Fachgesellschaften evidenzbasierte Statements und Empfehlungen (GRADE-System) zu Screening, Management und Behandlung von Zervixkarzinom-Vorstufen erarbeitet. Zwei unabhängige wissenschaftliche Institute haben systematische Reviews für diese Leitlinie erarbeitet.

Empfehlungen Der erste Teil dieser Kurzzusammenfassung behandelt pathologische Grundlagen und Fragen zum Screening. Ähnliche wie in früheren Reviews konnte auch die Metaanalyse durch Kleijnen Systematic Reviews einen besseren Schutz vor einem invasiven Zervixkarzinom durch ein HPV-basiertes Screening im Vergleich zur Zytologie zeigen. Daher empfiehlt die Leitliniengruppe - entsprechend den Richtlinien des Gemeinsamen Bundesauschusses (G-BA) - ein HPV-basiertes Screening mit Intervallen von mind. 3 Jahren für Frauen ab 35 Jahren. Ein Co-Testing kann ebenfalls durchgeführt werden. Frauen zwischen 20 und 35 sollten ein zytologisches Screening alle 2 Jahre erhalten.

\section{Guideline Information}

The Oncology Guidelines Program of the Association of Scientific Medical Societies in Germany (Arbeitsgemeinschaft der Wissenschaftlichen Medizinischen Fachgesellschaften e.V., AWMF), the German Cancer Society (Deutsche Krebsgesellschaft e. V., DKG) and German Cancer Aid (Deutsche Krebshilfe, DKH).

For more information, cf. the end of this article.

\section{Citation format}

Prevention of Cervical Cancer. Guideline of the DGGG and the DKG (S3 Level, AWMF Register Number 015/027OL, December 2017) - Part 1 with Introduction, Screening and the Pathology of Cervical Dysplasia. Geburtsh Frauenheilk 2019; 79: 148-159 


\section{Guideline documents}

The complete long version with a list of the conflicts of interest of all authors and a short version are available in German on the homepage of the Oncology Guidelines Program under: https://www.awmf.org/leitlinien/detail/I/015-027OL.html or www.leitlinienprogramm-onkologie.de

\section{Guideline authors}

The German Society of Gynecology and Obstetrics (DGGG, mandate holder Prof. Dr. Peter Hillemanns, Hanover) was the lead medical society responsible for the compilation of this guideline. The guideline is issued by the Oncological Guidelines Program. Every participating medical society nominated a mandate holder, with the board of the respective society confirming the mandate in writing by. $>$ Table 1 lists the societies and other organizations

- Table 1 Participating professional societies and other organizations.

\begin{tabular}{l} 
Participating professional societies and organizations \\
German Society of Gynecology and Obstetrics [Deutsche Gesellschaft für Gynäkologie und Geburtshilfe], (DGGG) \\
\hline German Society for Epidemiology [Deutsche Gesellschaft für Epidemiologie], (DGEpi) \\
\hline German Society for Virology [Deutsche Gesellschaft für Virologie e. V.], (GF) \\
\hline German Society of Pathology [Deutsche Gesellschaft für Pathologie e. V.], (DGP)
\end{tabular}

German STI Society [Deutsche STI-Gesellschaft e. V.], (DSTIG)

German Society for Cytology [Deutsche Gesellschaft für Zytologie], (DGZ)*

German Society for Medical Informatics, Biometry and Epidemiology

[Deutsche Gesellschaft für Medizinische Informatik, Biometrie und Epidemiologie e. V.], (GMDS)

Gynecological Oncology Working Group of the DKG [Arbeitsgemeinschaft für gynäkologische Onkologie der DKG], (AGO)

Self-help for Women after Cancer [Frauenselbsthilfe nach Krebs e. V.]

Professional Association of Gynecologists [Berufsverband der Frauenärzte e. V.], (BVF)*

Federal Association of Senior Physicians in Gynecology and Obstetrics

[Arbeitsgemeinschaft Leitender Ärztinnen und Ärzte in der Frauenheilkunde und Geburtshilfe e. V.], (BLFG)

Professional Association of German Physicians Working in Cytology

[Berufsverband zytologisch tätiger Ärzte in Deutschland e. V.], (AZÄD)*

Cervical Pathology and Colposcopy Working Group of the DGGG

[Arbeitsgemeinschaft Zervixpathologie und Kolposkopie der DGGG]*

Prevention and Integrative Oncology Working Group of the DKG, Section B

[Arbeitsgemeinschaft Prävention und integrative Onkologie (PRIO), DKG Sektion B]

HPV Management Forum of the Paul Ehrlich Society for Chemotherapy

[HPV-Management-Forum (Paul-Ehrlich-Gesellschaft für Chemotherapie PEG e.V.)]

Colposcopy Study Group [Studiengruppe Kolposkopie e. V.]

Working Group on Infections and Immunology of the DGGG

[Arbeitsgemeinschaft für Infektionen und Infektionsimmunologie der DGGG], (AGII)

German Cancer Research Center, (DKFZ)

International organizations

Gynecological Oncology and Breast Health Working Group of the SGGG

[Arbeitsgemeinschaft für gynäkologische Onkologie und Brustgesundheit (AGO) der (SGGG)] **

Gynecological Oncology of the OEGGG [Arbeitsgemeinschaft für gynäkologische Onkologie (AGO) der (OEGGG) ${ }^{* *}$

European Society of Gynaecological Oncology, (ESGO)***

\section{Mandate holder}

Christian Dannecker

Stefanie Klug

Thomas Iftner

Thomas Löning

Lars Horn (Deputy)

Dietmar Schmidt (Deputy)

Hans Ikenberg

Heinrich Neumann (till 14.08.2013)

Volker Schneider (till 12.05.2014)

Uwe Siebert

Willi Sauerbrei (Deputy)

Matthias Beckmann

Marion Gebhardt

Heidemarie Haase (Deputy)

Manfred Steiner

Ulrich Freitag (Deputy)

Michael Friedrich

Klaus Neis

Bodo Jordan (Deputy)

Wolfgang Kühn

Michael Menton (Deputy)

Karsten Münstedt

Achim Schneider

Andreas Kaufmann (Deputy)

K. Ulrich Petry

Axel P. A. Schäfer

Magnus von Knebel-Doeberitz

(till 25.06.2013)

Michael Pawlita

Mathias Fehr

Christoph Grimm

Olaf Reich (Deputy)

Rainer Kimmig

Martin Heubner (Deputy)

* $\quad$ AG-CPC, AZÄD, BVF and DGZ stepped down from participating in the compilation of the guideline on 12 May 2014 . After constructive discussions by the ad-hoc committee, BVF re-joined the guideline authors on 4 September 2017.

** These international medical societies participated in the consensus process but had no voting rights.

*** Although the ESGO nominated a mandate holder and a deputy, they did not participate in the compilation of this guideline. 
which participated in developing the guideline together with their respective mandated representatives. Only mandate holders nominated by participating societies and organizations were eligible to vote on a chapter-by-chapter basis during the voting process (consensus process) after they had disclosed and excluded any conflicts of interest. A patient representative was directly involved in the compilation of this guideline. Ms. Marion Gebhardt (Frauenselbsthilfe nach Krebs e.V. [Self-help for Women After Cancer]) was involved in developing the guideline right from the start and attended the consensus conferences where she had voting rights.

\section{Guideline Application}

\section{Purpose and objectives}

The creation of this $\mathrm{S} 3$ guideline meets an important need, outlined in the National Cancer Plan, with regard to screening for cervical cancer. The S3 guideline provides important information and support for the planned organized screening for cervical cancer in Germany.

The old S2k German-language guideline "Prevention, Diagnosis and Therapy of HPV Infections and Preinvasive Lesions of the Female Genitalia" was consulted, with the new guideline focusing on those aspects which deal with the cervix. The guideline recommendations for primary prevention were adopted from the updated S3 guideline on HPV vaccination and supplemented by additional information regarding the impact of HPV vaccination on screening. The S3 guideline on the Diagnosis and Therapy of Cervical Cancer published in 2014 covers all aspects of invasive cervical cancer.

\section{Targeted areas of patient care}

This S3 guideline on the prevention of cervical cancer covers the prevention of cervical cancer and the diagnosis, treatment and follow-up of cervical cancer including high-grade preinvasive cervical lesions. The most important goals of the guideline were analyzing the existing data to optimize screening for cervical cancer in terms of determining the optimal test procedures, organization, investigative algorithm and treatment and considering the question of how to encourage women who refuse to go for screening to participate in the program. In addition, the guideline investigated the impact of $\mathrm{HPV}$ vaccination on the screening strategy for cervical cancer.

\section{Target patient groups}

This S3 guideline is aimed at all women aged 20 and above.

\section{Target user groups/target audience}

The recommendations of the guideline are addressed to all physicians and professionals involved in screening for cervical cancer, in particular gynecologists, pathologists and cytologists, as well as all healthcare professionals working in dysplasia outpatient clinics and centers.

Other target groups include:

- scientific medical societies and professional associations which are involved in screening for cervical cancer,

- women's advocacy groups (women's health organizations, patient and self-help organizations),
- quality assurance organizations and similar projects on national and federal state levels,

- healthcare policy institutions and decision-makers at national and federal state levels,

- payers,

- the general public to inform them about what constitutes a good medical approach.

\section{Adoption and period of validity}

This guideline is valid from 31 December 2017 through to 31 December 2020. Because of the contents of the guideline, this period of validity is only an estimate. The guideline may need to be updated if new scientific evidence appears or the methodology used in the guideline is developed further. Moreover, the key statements and recommendations of the guideline should be subjected to regular editorial checks, and the contents of the guideline should be reviewed regularly.

\section{Methodology}

\section{Basic principles}

The method used to prepare this guideline was determined by the class to which this guideline was assigned. The AWMF Guidance Manual (version 1.0) has set out the respective rules and requirements for different classes of guidelines. Guidelines are differentiated into lowest (S1), intermediate (S2) and highest (S3) class. The lowest class is defined as a set of recommendations for action compiled by a non-representative group of experts. In 2004, the S2 class was divided into two subclasses: a systematic evidencebased subclass (S2e) and a structural consensus-based subclass (S2k). The highest S3 class combines both approaches. This guideline is classified as: S3.

\section{Grading of evidence}

The GRADE (GRADE = Grading of Recommendations Assessment, Development and Evaluation) system developed by the GRADE Working Group [1] (www.gradeworkinggroup.org) was used to evaluate the quality of evidence of the studies identified and used for this guideline ( $\triangleright$ Table 2 ).

- Table 2 Grading of quality of evidence based on the GRADE system.

\begin{tabular}{|l|l|c|}
\hline GRADE & Description & Symbol \\
\hline \begin{tabular}{l|l|l|}
\hline High \\
quality
\end{tabular} & $\begin{array}{l}\text { "We are very confident that the true effect lies } \\
\text { close to that of the estimate of the effect." }\end{array}$ & $\oplus \oplus \oplus \oplus$ \\
\hline $\begin{array}{l}\text { Moderate } \\
\text { quality }\end{array}$ & $\begin{array}{l}\text { "We are moderately confident in the effect esti- } \\
\text { mate: The true effect is likely to be close to the es- } \\
\text { timate of the effect, but there is a possibility that it } \\
\text { is substantially different." }\end{array}$ & $\oplus \oplus \oplus \ominus$ \\
\hline \begin{tabular}{l|l} 
Low \\
quality
\end{tabular} & $\begin{array}{l}\text { "Our confidence in the effect estimate is limited: } \\
\text { the estimate of the effect." }\end{array}$ & $\oplus \oplus \ominus \ominus$ \\
\hline $\begin{array}{l}\text { Very low } \\
\text { quality }\end{array}$ & $\begin{array}{l}\text { "We have very little confidence in the effect esti- } \\
\text { mate: The true effect is likely to be substantially } \\
\text { different from the estimate of effect." }\end{array}$ & $\oplus \ominus \ominus \ominus$ \\
\hline
\end{tabular}




\section{Grading of recommendations}

The methodology of the Oncology Guidelines Program requires guideline authors to assign a level of recommendation to each recommendation indicating the strength of the recommendation. The strength of each recommendation is agreed upon during a formal consensus process which requires structured consensus conferences [2]. (Details are available from the German-language Guideline Report). As part of the process, mandate holders with voting rights formally voted on the recommendations of this guideline.

This guideline includes information on the grading of the evidence of the underlying studies used for all evidence-based Statements and Recommendations and additionally shows the strength of each recommendation (level of recommendation). As outlined in the AWMF Guidance Manual [2], this guideline differentiates between three strengths or levels of recommendation, and the respective level of recommendation is reflected by the syntax used in the recommendation ( $\bullet$ Table 3 ).

The decision criteria used to determine the level of recommendation are explained in the German-language Guideline Report for this guideline.

Table 3 Level of recommendation.

\begin{tabular}{|l|l|l|}
\hline $\begin{array}{l}\text { Level of } \\
\text { recommendation }\end{array}$ & Description & Syntax \\
\hline A & Strong recommendation & must \\
\hline B & Recommendation & should \\
\hline 0 & Open recommendation & may \\
\hline
\end{tabular}

\section{Statements}

Statements are expositions or explanations of specific facts, circumstances, or problems, with no direct recommendations for action. Statements are adopted after a formal consensus process using the same approach as that used when formulating recommendations and can be based either on study results or expert opinions ( $\triangleright$ Table 4: Level of consensus).

- Table 4 Level of consensus.

\begin{tabular}{|l|l|}
\hline Level of consensus & Extent of agreement in percent \\
\hline Strong consensus & $>95 \%$ of participants entitled to vote agree \\
\hline Consensus & $>75-95 \%$ of participants entitled to vote agree \\
\hline Majority agreement & $>50-75 \%$ of participants entitled to vote agree \\
\hline No consensus & $<50 \%$ of participants entitled to vote agree \\
\hline
\end{tabular}

\section{Expert consensus (EC)}

Statements/Recommendations which were based on the expert consensus of the guideline authors are marked as expert consensus. No symbols or letters were used to grade the expert consensus; the respective level of consensus is shown by the syntax used (must/should/may) based on the differentiation described in - Table 3.

\section{Guideline \\ 1 Pathological, Cytological and Virological Basis}

\begin{tabular}{|c|c|c|c|c|}
\hline No. & $\begin{array}{l}\text { Recommendations/ } \\
\text { Statements }\end{array}$ & EG & LoE & Sources \\
\hline 3.1. & $\begin{array}{l}\text { The previous (Munich II) classifi- } \\
\text { cation of cytological findings } \\
\text { must be switched to the new } \\
\text { Munich III nomenclature but } \\
\text { without including the recom- } \\
\text { mendations of the new nomen- } \\
\text { clature. }\end{array}$ & EC & & \\
\hline 1.2. & $\begin{array}{l}\text { The classic } 3 \text {-tiered classification } \\
\text { into CIN } 1 \text {, CIN } 2 \text { and CIN } 3 \text { will } \\
\text { continue to be used. The } 2 \text {-tiered } \\
\text { classification used by the WHO } \\
\text { (LSIL/HSIL) must be added in } \\
\text { parentheses or as a comment. }\end{array}$ & EC & & \\
\hline 1.3. & $\begin{array}{l}\text { p16 immunohistochemistry } \\
\text { should only be used to obtain a } \\
\text { differential diagnosis to differen- } \\
\text { tiate cervical findings from reac- } \\
\text { tive and regenerative cervical } \\
\text { changes which mimic intraepi- } \\
\text { thelial neoplasia. }\end{array}$ & EC & & \\
\hline
\end{tabular}

\section{$2 \quad$ Epidemiology}

Cervical cancer is the third most common cancer in women worldwide. The incidence and mortality rates vary considerably. Particularly in less developed countries, many women still die from cervical cancer every year.

In Germany, the incidence rate standardized for age (European standard) was 9.3 per 100000 in 2012 . The actual raw incidence rate for Germany in 2012 was 11.3 per 100000 . The introduction of cancer screening using Pap smears in 1971 contributed to a significant decrease in incidence and mortality rates in Germany. However, in recent years, incidence and mortality rates in Germany have stagnated.

Persistent infection with human papillomavirus is the main cause of cervical cancer. The prevalence of HPV is particularly high in young women under the age of 30 . HPV 16 is the most common HPV type worldwide. HPV types 16 and 18 are responsible for 60 to $70 \%$ of all cervical carcinomas.

\section{Primary Prevention (HPV Vaccination)}

The following items from the HPV vaccination guideline 082/002 [3] represent a summary of the recommendations made by the guideline authors. 


\begin{tabular}{|c|c|c|c|c|}
\hline No. & Recommendations/Statements & EG & LoE & Sources \\
\hline 5.1. & $\begin{array}{l}\text { Prior testing for HPV is not recommended as an aid to decision-making about whether to vaccinate against HPV } \\
\text { or not. Such testing would only lead to additional costs, stresses and anxieties. Vaccination should still be carried } \\
\text { out even in women positive for HPV because, in it is rare for women to be simultaneously be infected with all HPV } \\
\text { types for which there are vaccines. }\end{array}$ & EC & & \\
\hline 5.2 . & $\begin{array}{l}\text { All girls aged } 9 \text { years and above must be vaccinated as soon as possible against HPV. As both vaccines have been } \\
\text { approved for use in this age group, girls of this age can be vaccinated. Early vaccination also offers protection } \\
\text { against infections which are not transmitted through sexual contact. }\end{array}$ & EC & & \\
\hline 5.3. & $\begin{array}{l}\text { The expected benefit of vaccination may be reduced once girls begin to be sexually active. For persons who are } \\
\text { already sexually active, the decision whether to vaccinate or not should be made on a case by case basis. }\end{array}$ & EC & & \\
\hline 5.4 . & $\begin{array}{l}\text { It is not recommended to treat existing CIN or ICC with vaccination as there is no evidence that it is effective. } \\
\text { However, there are indications that HPV vaccination can prevent recurrence after surgical therapy. HPV vaccina- } \\
\text { tion may be considered as part of surgical treatment to reduce the risk of recurrence. }\end{array}$ & EC & & \\
\hline 5.5 . & $\begin{array}{l}\text { At the present point in time, women who are vaccinated against HPV should continue to attend screening } \\
\text { sessions as the currently available vaccines do not prevent all forms of oncogenic HPV infection. }\end{array}$ & EC & & \\
\hline
\end{tabular}

\section{Secondary Prevention - Cytology}

\begin{tabular}{|c|c|c|c|c|}
\hline No. & Recommendations/Statements & EG & LoE & Sources \\
\hline 6.1. & $\begin{array}{l}\text { A standard cytological Pap smear obtained from the uterine cervix uteri must contain sufficient epithelial cells } \\
\text { from the transformation zone; the cells must be spread as evenly as possible across the slide and must be ade- } \\
\text { quately fixed and stained. }\end{array}$ & \multicolumn{3}{|l|}{ EC } \\
\hline 6.2. & $\begin{array}{l}\text { The collection of cells for a standard cytological Pap smear must be done using a collection instrument approved } \\
\text { by the Cancer Screening Guideline, and cells must be fixed immediately after collection in } 96 \% \text { alcohol for } \\
10 \text { minutes or using a special fixation spray. }\end{array}$ & \multicolumn{3}{|l|}{ EC } \\
\hline 6.3. & $\begin{array}{l}\text { When collecting cells for thin-layer cytology the recommended collection instrument must be immediately } \\
\text { transferred into the approved fixation solution. }\end{array}$ & \multicolumn{3}{|l|}{ EC } \\
\hline 6.4. & $\begin{array}{l}\text { There is no evidence that thin-layer cytology differs from standard Pap smear cytology in terms of its accuracy } \\
\text { in detecting CIN 2+. }\end{array}$ & \multicolumn{2}{|l|}{$\oplus \ominus \ominus \ominus$} & {$[4-18]$} \\
\hline 6.5. & $\begin{array}{l}\text { Thin-layer cytology may be used for screening. } \\
\text { Additional tests may be carried out using the specimens collected for thin-layer cytology without having to recall } \\
\text { the woman for a separate appointment. }\end{array}$ & \multicolumn{3}{|l|}{ EC } \\
\hline 6.6. & $\begin{array}{l}\text { There is no evidence that computer-assisted cytology differs from standard Pap smear cytology in terms of its } \\
\text { accuracy in detecting CIN } 2+\text {. }\end{array}$ & \multicolumn{2}{|l|}{$\oplus \ominus \ominus \ominus$} & $\begin{array}{l}{[17,19-} \\
27]\end{array}$ \\
\hline 6.7. & $\begin{array}{l}\text { There is no evidence that computer-assisted cytology differs from manual thin-layer cytology in terms of its } \\
\text { accuracy in detecting CIN } 2+\text {. }\end{array}$ & \multicolumn{2}{|l|}{$\oplus \ominus \ominus \ominus$} & $\begin{array}{l}{[17,25,} \\
28-42]\end{array}$ \\
\hline 6.8. & Computer-assisted cytology may be used for screening. & \multicolumn{3}{|l|}{ EC } \\
\hline 5 & \multicolumn{4}{|l|}{ Secondary Prevention - HPV } \\
\hline 5.1 & \multicolumn{4}{|l|}{ Suitable HPV tests } \\
\hline No. & Recommendations/Statements & EG & LoE & Sources \\
\hline 7.1. & $\begin{array}{l}\text { Only HPV tests which meet the following criteria (based on Meijer et al. and Stoler et al.) must be used: } \\
\text { 1. Can detect high-risk HPV types } 16,18,31,33,35,39,45,51,52,56,58,59 \text { and } 68 \text {. } \\
\text { 2. Has at least } 90 \% \text { of the sensitivity of an established and validated HPV test for CIN2+. } \\
\text { 3. Has at least } 98 \% \text { of the specificity of an established and validated HPV test for CIN2+. The percentage of } \\
\text { positive test results in a screening population consisting of women who are cytologically negative must not } \\
\text { be higher than the percentage found with validated and established HPV tests. } \\
\text { Single-laboratory and inter-laboratory agreement (achieved by different personnel and on different machines) } \\
\text { should be at least } 90 \% \text {. }\end{array}$ & \multicolumn{3}{|l|}{ EC } \\
\hline 7.2. & The HPV test used for investigation must be stated on the test results. & \multicolumn{3}{|l|}{ EC } \\
\hline
\end{tabular}




\subsection{Comparison of HPV screening alone or combined with cytology and cytological screening}

\begin{tabular}{|c|c|c|c|}
\hline No. & Recommendations/Statements & GRADE & Sources \\
\hline 7.3. & $\begin{array}{l}\text { In women aged } 30 \text { and above, organized screening programs based on an HPV test alone or an HPV test com- } \\
\text { bined with cytology and carried out at regular intervals of } 3 \text { or } 5 \text { years lead to a significant reduction in the } \\
\text { number of new cases with cervical cancer }(6 / 100000) \text { in the second round of screening after three or five years } \\
\text { compared to organized screening programs carried out at regular intervals of } 3 \text { or } 5 \text { years which are based on } \\
\text { cytological screening alone (20/100 000; RR 0.29). }\end{array}$ & $\oplus \ominus \ominus \ominus$ & $\begin{array}{l}{[15,43-} \\
59]\end{array}$ \\
\hline 7.4 . & $\begin{array}{l}\text { In women aged } 30 \text { years and above, organized screening programs carried out at regular intervals of } 3 \text { or } 5 \text { years } \\
\text { which are based on testing for HPV alone or testing for HPV combined with cytology lead to a significant reduc- } \\
\text { tion in the number of new cases with CIN } 3+(82 / 100000) \text { in the second round of screening after three or five } \\
\text { years compared to organized screening programs carried out at regular intervals of } 3 \text { or } 5 \text { years which are based } \\
\text { on cytological screening alone (159/100 000; RR 0.59). }\end{array}$ & $\oplus \oplus \oplus \ominus$ & $\begin{array}{l}{[15,48-} \\
61]\end{array}$ \\
\hline
\end{tabular}

\subsection{Potential patient-relevant disadvantages of HPV-based screening}

\begin{tabular}{|l|l|l|l|}
\hline No. & Recommendations/Statements & GRADE & Sources \\
\hline 7.5. & There is no evidence that there is any difference in the level of psychological stress experienced by women & $\oplus \oplus \oplus \ominus$ \\
who have HPV-based screening compared to women who have cytological screening every 3 years. & {$[60,61]$} \\
\hline
\end{tabular}

\begin{tabular}{|c|c|c|c|}
\hline No. & Recommendations/Statements & GRADE & Sources \\
\hline 7.6. & $\begin{array}{l}\text { HPV-based screening and HPV test + cytology-based screening carried out every } 3 \text { or } 5 \text { years result in the } \\
\text { detection of more cases with CIN } 2 \text { compared to cytology-based screening carried out every } 3 \text { or } 5 \text { years. } \\
\text { This also increases the risk of overdiagnosis and overtreatment in the population being screened. This disad- } \\
\text { vantage is particularly pronounced in women under the age of } 30 \text { years. Shorter intervals between screening } \\
\text { examinations increase the risk of overdiagnosis and overtreatment. } \\
\text { The use of triage tests reduces overdiagnosis and overtreatment. }\end{array}$ & EC & \\
\hline
\end{tabular}

\section{Start and End of Screening, Intervals between Screening, Special Screening Situations}

\subsection{Start of Screening}

\begin{tabular}{|c|c|c|c|}
\hline No. & Recommendations/Statements & GRADE & Sources \\
\hline 8.1. & $\begin{array}{l}\text { For women under the age of } 25 \text { years, there are no indications that the benefits of organized cervical cancer } \\
\text { screening outweigh the harm. }\end{array}$ & \multicolumn{2}{|l|}{ EC } \\
\hline 8.2. & $\begin{array}{l}\text { Organized screening for cervical cancer can be started when women are aged } 25 \text { years. } \\
\text { In Germany, women above the age of } 20 \text { are still entitled to have a screening test in accordance with the } \\
\text { screening guideline (key points of the resolution regarding the Cancer Screening Guideline [KFE-RL] passed } \\
\text { on } 15 \text { September 2016). }\end{array}$ & \multicolumn{2}{|l|}{ EC } \\
\hline 8.3. & $\begin{array}{l}\text { Better detection rates of CIN } 3 \text { + have been reported for organized HPV-based screening in women between the } \\
\text { ages of } 25 \text { and } 30 \text {, but this also leads to a high rate of false-positive results. }\end{array}$ & $\oplus \ominus \ominus \ominus$ & $\begin{array}{l}{[15,54-} \\
59]\end{array}$ \\
\hline 8.4. & Organized HPV-based screening (HPV or HPV + cytology) should not be carried out in women under the age of 30. & $\begin{array}{l}\oplus \ominus \ominus \ominus \\
B\end{array}$ & $\begin{array}{l}{[15,48-} \\
59]\end{array}$ \\
\hline 8.5. & In Germany, women between 20 and 35 are still entitled to have organized cytology-based screening. & & \\
\hline
\end{tabular}




\begin{tabular}{|c|c|c|c|}
\hline No. & Recommendations/Statements & GRADE & Sources \\
\hline 8.6. & $\begin{array}{l}\text { In women aged } 30 \text { years and above, organized HPV-based screening carried out every } 3 \text { to } 5 \text { years results in lower } \\
\text { rates of new cases with cervical cancer compared to organized screening based on cytology alone carried out } \\
\text { every } 3 \text { years. }\end{array}$ & $\oplus \ominus \ominus \ominus$ & $\begin{array}{l}{[15,48-} \\
59]\end{array}$ \\
\hline 8.7. & $\begin{array}{l}\text { There is no evidence that cytological screening carried out annually is superior to cytological screening carried } \\
\text { out every two years. }\end{array}$ & \multicolumn{2}{|l|}{ EC } \\
\hline 8.8. & $\begin{array}{l}\text { In Germany, during the transition period (at least another } 6 \text { years or until sufficient data is available from the } \\
\text { 2nd round of screening) women between the age of } 20 \text { and } 35 \text { will still be entitled to have an annual cytological } \\
\text { examination. After the end of the transition period, the intervals between screening appointments and the } \\
\text { screening method itself must be adapted to conform to international recommendations after the data used to } \\
\text { monitor this age group has been taken into account. } \\
\text { In future, women aged } 35 \text { and above will be offered a combined screening examination consisting of an HPV test } \\
\text { and a cytological examination instead of an annual cytological examination every } 3 \text { years. }\end{array}$ & \multicolumn{2}{|c|}{$\begin{array}{l}\text { G-BA: Presse release of } 16 \text { Sep- } \\
\text { tember 2016, No. 38/2016: } \\
\text { “Eckpunkte für zukünftiges } \\
\text { Screening auf Gebärmutter- } \\
\text { halskrebs geändert”. Available } \\
\text { online at: https://www.g-ba. } \\
\text { de/institution/presse/ } \\
\text { pressemitteilungen/641. }\end{array}$} \\
\hline 8.9. & $\begin{array}{l}\text { If co-testing (cytology and HPV test) or HPV testing alone is done in women above the age of } 30 \text {, it should } \\
\text { be carried in the form of organized screening at intervals of least } 3 \text { years. }\end{array}$ & EC & \\
\hline
\end{tabular}

\subsection{End of screening}

\begin{tabular}{|l|l|l|l|}
\hline No. & Recommendations/Statements & GRADE & Sources \\
\hline \begin{tabular}{l|l|} 
8.10. & RCTs have only investigated women up to the age of 65. The benefit of organized screening in women aged more \\
than 65 years is therefore not proven, irrespective of whether screening is based on HPV and/or cytology.
\end{tabular} & EC \\
\hline $\begin{array}{l}\text { 8.11. } \\
\text { Women over the age of } 65 \text { must be encouraged to continue participating in cancer screening programs. Dis- } \\
\text { continuing screening for cervical cancer may be considered for women over the age of } 65 \text { who have had multiple } \\
\text { negative results following co-testing with a Pap smear and an HPV test. }\end{array}$ & EC \\
\hline
\end{tabular}

6.4 What screening is recommended for women who have been vaccinated against HPV?
No. Recommendations/Statements
8.12. Women who have been vaccinated against HPV have a lower risk of developing CIN 3+.
In Germany, cancer screening is offered to women irrespective of whether they have been vaccinated or not.

\begin{tabular}{l|l} 
GRADE & Sources \\
\hline EC & \\
\hline
\end{tabular}

6.5 What screening is recommended for women who have undergone a hysterectomy?

\begin{tabular}{|l|l|l|l|}
\hline No. & Recommendations/Statements & GRADE & Sources \\
\hline 8.13. & $\begin{array}{l}\text { The benefit of screening for women who have undergone total hysterectomy is not proven, irrespective } \\
\text { of whether the screening is based on cytology or on testing for HPV. }\end{array}$ & EC \\
\hline 8.14. & $\begin{array}{l}\text { HPV-positive Frauen who have undergone total hysterectomy should continue to participate in organized } \\
\text { screening programs. }\end{array}$ & EC \\
\hline 8.15. & $\begin{array}{l}\text { Women who have undergone supracervical hysterectomy must continue to participate in organized screening } \\
\text { programs. }\end{array}$ & EC \\
\hline
\end{tabular}

\subsection{What screening is recommended for immunosuppression?}

\begin{tabular}{|l|l|l|l|l|l|}
\hline No. & Recommendations/Statements & SRADE \\
\hline 8.16. & $\begin{array}{l}\text { Immunosuppressed women have a higher risk of developing precancerous cervical conditions and invasive } \\
\text { cervical cancer. }\end{array}$ & EC \\
\hline 8.17. & $\begin{array}{l}\text { Immunosuppressed women with abnormal findings on screening must be referred to a certified dysplasia } \\
\text { outpatient clinic/facility. }\end{array}$ & EC \\
\hline
\end{tabular}




\section{$7 \quad$ Biomarkers}

7.1 Is primary screening with a biomarker superior to HPV DNA analysis?

\begin{tabular}{|c|c|c|c|}
\hline No. & Recommendations/Statements & GRADE & Sources \\
\hline 9.1. & $\begin{array}{l}\text { Cross-sectional studies have found no benefits of using biomarkers (5-type HPV mRNA, p16 ELISA, ProExC, } \\
\text { p16/Ki-67 dual staining, protein E6) compared to high-risk HPV DNA testing. }\end{array}$ & $\oplus \oplus \ominus \ominus$ & [62-71] \\
\hline 9.2. & $\begin{array}{l}\text { There are currently no data from longitudinal studies of more than } 3 \text { years for the biomarkers currently } \\
\text { being tested in large studies, meaning that these biomarkers must not be used for primary screening. }\end{array}$ & $\begin{array}{l}\oplus \oplus \ominus \ominus \\
A\end{array}$ & [62-71] \\
\hline
\end{tabular}

7.2 Is primary screening with a biomarker superior to conventional cytology?

\begin{tabular}{|l|l|l|l|}
\hline No. & Recommendations/Statements & GRADE & Sources \\
\hline 9.3. & $\begin{array}{l}\text { Sensitivity: In cross-sectional studies, biomarkers (5-type HPV mRNA, p16 ELISA, ProExC, p16/Ki-67 } \\
\text { dual staining, protein E6) are superior to conventional cytology with regard to sensitivity. } \\
\text { Specificity: p16/Ki-67 dual staining is superior to conventional cytology with regard to specificity. }\end{array}$ & $\begin{array}{l}\oplus \oplus \ominus \ominus \\
\text { [63-66, } \\
68-70]\end{array}$ \\
\hline 9.4. & $\begin{array}{l}\text { Biomarkers (5-type HPV mRNA, p16 ELISA, ProExC, p16/Ki-67 dual staining, protein E6) must not be used for } \\
\text { primary screening as long as the suitability of these procedures has not yet been verified in longitudinal studies } \\
\text { of at least 5 years. }\end{array}$ & $\begin{array}{c}\oplus \oplus \ominus \ominus \\
\text { A }\end{array}$ & $\begin{array}{l}\text { [63-66, } \\
68-70]\end{array}$ \\
\hline
\end{tabular}

\section{Conflict of Interest}

See guideline report: https://www.awmf.org/uploads/tx_szleitlinien/ 015-027OLm_Praevention_Zervixkarzinom_2018-01.pdf

\section{References}

[1] Balshem H, Helfand M, Schunemann HJ et al. GRADE guidelines: 3. Rating the quality of evidence. J Clin Epidemiol 2011; 64: 401-406

[2] Arbeitsgemeinschaft der Wissenschaftlichen Medizinischen Fachgesellschaften (AWMF) - Ständige Kommission Leitlinien. AWMF-Regelwerk „Leitlinien“. 2012. Online: http://www.awmf.org/leitlinien/awmfregelwerk.html; last access: 10.11.2015

[3] Gross G et al. Impfprävention HPV-assoziierter Neoplasien. 2013. Online: http://www.awmf.org/leitlinien/detail/II/082-002.html; last access: 29.10.2013

[4] Angstetra D, Tait T, Tan J et al. Should liquid-based cytology be performed prior to colposcopy? A comparison of the accuracy, unsatisfactory rates and cost in a tertiary referral setting. Aust N Z J Obstet Gynaecol 2009; 49: 681-684

[5] Bergeron C, Bishop J, Lemarie A et al. Accuracy of thin-layer cytology in patients undergoing cervical cone biopsy. Acta Cytol 2001; 45: 519-524

[6] Confortini M, Bulgaresi P, Cariaggi MP et al. Comparing conventional and liquid-based smears from a consecutive series of 297 subjects referred to colposcopy assessment. Cytopathology 2004; 15: 168-170

[7] Confortini M, Carozzi F, Cortecchia S et al. Technical evaluation of the new thin layer device CellSlide (Menarini Diagnostics). Diagn Cytopathol 2005; 33: 387-393

[8] Coste J, Cochand-Priollet B, de Cremoux P et al. Cross sectional study of conventional cervical smear, monolayer cytology, and human papillomavirus DNA testing for cervical cancer screening. BMJ 2003; 326: 733

[9] Ferenczy A, Franco E, Arseneau J et al. Diagnostic performance of Hybrid Capture human papillomavirus deoxyribonucleic acid assay combined with liquid-based cytologic study. Am J Obstet Gynecol 1996; 175 (3 Pt 1): 651-656
[10] Hussein T, Desai M, Tomlinson A et al. The comparative diagnostic accuracy of conventional and liquid-based cytology in a colposcopic setting. BJOG 2005; 112: 1542-1546

[11] Jesdapatarakul S, Tangjitgamol S, Nguansangiam S et al. Liqui-Prep(R) versus conventional Papanicolaou smear to detect cervical cells abnormality by split-sample technique: a randomized double-blind controlled trial. Diagn Cytopathol 2011; 39: 22-27

[12] Longatto Filho A, Pereira SM, Di Loreto $C$ et al. DCS liquid-based system is more effective than conventional smears to diagnosis of cervical lesions: study in high-risk population with biopsy-based confirmation. Gynecol Oncol 2005; 97: 497-500

[13] Sykes PH, Harker DY, Miller A et al. A randomised comparison of SurePath liquid-based cytology and conventional smear cytology in a colposcopy clinic setting. BJOG 2008; 115: 1375-1381

[14] Taylor S, Kuhn L, Dupree W et al. Direct comparison of liquid-based and conventional cytology in a South African screening trial. Int J Cancer 2006; 118: 957-962

[15] Ronco G, Cuzick J, Pierotti P et al. Accuracy of liquid based versus conventional cytology: Overall results of new technologies for cervical cancer screening: Randomised controlled trial. BMJ 2007; 335: 28-31

[16] Siebers AG, Klinkhamer PJ, Grefte JM et al. Comparison of liquid-based cytology with conventional cytology for detection of cervical cancer precursors: a randomized controlled trial. JAMA 2009; 302: 1757-1764

[17] Klug SJ, Neis KJ, Harlfinger W et al. A randomized trial comparing conventional cytology to liquid-based cytology and computer assistance. Int J Cancer 2013; 132: 2849-2857

[18] Strander B, Andersson-Ellstrom A, Milsom I et al. Liquid-based cytology versus conventional Papanicolaou smear in an organized screening program: a prospective randomized study. Cancer 2007; 111: 285-291

[19] Wilbur DC, Prey MU, Miller WM et al. Detection of high grade squamous intraepithelial lesions and tumors using the AutoPap System: results of a primary screening clinical trial. Cancer 1999; 87: 354-358

[20] Wilbur DC, Parker EM, Foti JA. Location-guided screening of liquid-based cervical cytology specimens: a potential improvement in accuracy and productivity is demonstrated in a preclinical feasibility trial. Am J Clin Pathol 2002; 118: 399-407 
[21] Confortini M, Bonardi L, Bulgaresi P et al. A feasibility study of the use of the AutoPap screening system as a primary screening and locationguided rescreening device. Cancer 2003; 99: 129-134

[22] Stevens MW, Milne AJ, Parkinson IH et al. Effectiveness of AutoPap system location-guided screening in the evaluation of cervical cytology smears. Diagn Cytopathol 2004; 31: 94-99

[23] Passamonti B, Bulletti S, Camilli M et al. Evaluation of the FocalPoint GS system performance in an Italian population-based screening of cervical abnormalities. Acta Cytol 2007; 51: 865-871

[24] Bowditch RC, Clarke JM, Baird PJ et al. Results of an Australian trial using SurePath liquid-based cervical cytology with FocalPoint computer-assisted screening technology. Diagn Cytopathol 2012; 40: 1093-1099

[25] Roberts JM, Thurloe JK, Bowditch RC et al. A three-armed trial of the ThinPrep Imaging System. Diagn Cytopathol 2007; 35: 96-102

[26] Davey E, d'Assuncao J, Irwig L et al. Accuracy of reading liquid based cytology slides using the ThinPrep Imager compared with conventional cytology: prospective study. BMJ (Clinical research ed.) 2007; 335: 31

[27] Halford JA, Batty T, Boost T et al. Comparison of the sensitivity of conventional cytology and the ThinPrep Imaging System for 1,083 biopsy confirmed high-grade squamous lesions. Diagn Cytopathol 2010; 38: 318-326

[28] Wilbur DC, Black-Schaffer WS, Luff RD et al. The Becton Dickinson FocalPoint GS Imaging System: clinical trials demonstrate significantly improved sensitivity for the detection of important cervical lesions. Am J Clin Pathol 2009; 132: 767-775

[29] Levi AW, Chhieng DC, Schofield K et al. Implementation of FocalPoint GS location-guided imaging system: experience in a clinical setting. Cancer Cytopathol 2012; 120: 126-133

[30] Stein MD, Fregnani JHTG, Scapulatempo C et al. Performance and reproducibility of gynecologic cytology interpretation using the FocalPoint system: results of the RODEO Study Team. Am J Clin Pathol 2013; 140: 567-571

[31] Biscotti CV, Dawson AE, Dziura B et al. Assisted primary screening using the automated ThinPrep Imaging System. Am J Clin Pathol 2005; 123: 281-287

[32] Dziura B, Quinn S, Richard K. Performance of an imaging system vs. manual screening in the detection of squamous intraepithelial lesions of the uterine cervix. Acta Cytol 2006; 50: 309-311

[33] Lozano R. Comparison of computer-assisted and manual screening of cervical cytology. Gynecol Oncol 2007; 104: 134-138

[34] Bolger N, Heffron C, Regan I et al. Implementation and evaluation of a new automated interactive image analysis system. Acta Cytol 2006; 50: 483-491

[35] Chivukula M, Saad RS, Elishaev E et al. Introduction of the Thin Prep Imaging System (TIS): experience in a high volume academic practice. Cytojournal 2007; 4: 6

[36] Miller FS, Nagel LE, Kenny-Moynihan MB. Implementation of the ThinPrep imaging system in a high-volume metropolitan laboratory. Diagn Cytopathol 2007; 35: 213-217

[37] Papillo JL, St John TL, Leiman G. Effectiveness of the ThinPrep Imaging System: clinical experience in a low risk screening population. Diagn Cytopathol 2008; 36: 155-160

[38] Pacheco MC, Conley RC, Pennington DW et al. Concordance between original screening and final diagnosis using imager vs. manual screen of cervical liquid-based cytology slides. Acta Cytol 2008; 52: 575-578

[39] Duby JM, DiFurio MJ. Implementation of the ThinPrep Imaging System in a tertiary military medical center. Cancer 2009; 117: 264-270

[40] Kitchener HC, Blanks R, Dunn G et al. Automation-assisted versus manual reading of cervical cytology (MAVARIC): a randomised controlled trial. Lancet Oncol 2011; 12: 56-64
[41] Palmer T], Nicoll SM, McKean ME et al. Prospective parallel randomized trial of the MultiCyte ${ }^{\mathrm{TM}}$ ThinPrep $\left({ }^{\circledR}\right)$ imaging system: the Scottish experience. Cytopathology 2013; 24: 235-245

[42] Ha SY, Lee YK, Oh YL. Effectiveness of the ThinPrep Imaging System in the detection of abnormal cervicovaginal cytology: a practical experience in Korea. Acta Cytol 2013; 57: 159-163

[43] Budenholzer B. ACP Journal Club. Adding HPV testing to cytology screening reduced $\geq$ grade 3 cervical intraepithelial neoplasia at 5 years. Ann Intern Med 2012; 157: JC2-6, JC2-7

[44] Bulkmans NWJ, Rozendaal L, Snijders PJF et al. POBASCAM, a populationbased randomized controlled trial for implementation of high-risk HPV testing in cervical screening: design, methods and baseline data of 44,102 women. Int J Cancer 2004; 110: 94-101

[45] Bulkmans NW], Bulk S, Ottevanger MS et al. Implementation of human papillomavirus testing in cervical screening without a concomitant decrease in participation rate. J Clin Pathol 2006; 59: 1218-1220

[46] Bulkmans NWJ, Berkhof J, Rozendaal L et al. Human papillomavirus DNA testing for the detection of cervical intraepithelial neoplasia grade 3 and cancer: 5-year follow-up of a randomised controlled implementation trial. Lancet 2007; 370: 1764-1772

[47] Rijkaart DC, Berkhof J, Rozendaal L et al. Human papillomavirus testing for the detection of high-grade cervical intraepithelial neoplasia and cancer: Final results of the POBASCAM randomised controlled trial. Lancet Oncol 2012; 13: 78-88

[48] Kitchener HC, Almonte M, Wheeler P et al. HPV testing in routine cervical screening: cross sectional data from the ARTISTIC trial. $\mathrm{Br}$ J Cancer 2006; 95: 56-61

[49] Kitchener HC, Fletcher I, Roberts C et al. The psychosocial impact of human papillomavirus testing in primary cervical screening-a study within a randomized trial. Int J Gynecol Cancer 2008; 18: 743-748

[50] Kitchener HC, Almonte M, Thomson C et al. HPV testing in combination with liquid-based cytology in primary cervical screening (ARTISTIC): a randomised controlled trial. Lancet Oncol 2009; 10: 672-682 [Erratum in: Lancet Oncol 2009; 10: 748]

[51] Kitchener HC, Almonte M, Gilham C et al. ARTISTIC: a randomised trial of human papillomavirus (HPV) testing in primary cervical screening. Health Technol Assess (Rockv) 2009; 13: 1-150, iii-iv

[52] Sargent A, Bailey A, Turner A et al. Optimal threshold for a positive hybrid capture 2 test for detection of human papillomavirus: data from the ARTISTIC trial. J Clin Microbiol 2010; 48: 554-558

[53] Kitchener HC, Gilham C, Sargent A et al. A comparison of HPV DNA testing and liquid based cytology over three rounds of primary cervical screening: extended follow up in the ARTISTIC trial. Eur J Cancer 2011. 47: 864-871

[54] Giorgi-Rossi P, Segnan N, Zappa M et al. The impact of new technologies in cervical cancer screening: results of the recruitment phase of a large randomised controlled trial from a public health perspective. Int J Cancer 2007; 121: 2729-2734

[55] Ronco G, Segnan N, Giorgi-Rossi P et al. Human papillomavirus testing and liquid-based cytology: results at recruitment from the new technologies for cervical cancer randomized controlled trial. J Natl Cancer Inst 2006; 98: 765-774

[56] Ronco G, Giorgi-Rossi P, Carozzi F et al. Human papillomavirus testing and liquid-based cytology in primary screening of women younger than 35 years: results at recruitment for a randomised controlled trial. Lancet Oncol 2006; 7: 547-555

[57] Ronco G, Cuzick J, Segnan N et al. HPV triage for low grade (L-SIL) cytology is appropriate for women over 35 in mass cervical cancer screening using liquid based cytology. Eur J Cancer 2007; 43: 476-480

[58] Ronco G, Giorgi-Rossi P, Carozzi F et al. Results at recruitment from a randomized controlled trial comparing human papillomavirus testing alone with conventional cytology as the primary cervical cancer screening test. J Natl Cancer Inst 2008; 100: 492-501 
[59] Ronco G, Giorgi-Rossi P, Carozzi F et al. Efficacy of human papillomavirus testing for the detection of invasive cervical cancers and cervical intraepithelial neoplasia: a randomised controlled trial. Lancet Oncol 2010; 11: 249-257

[60] Elfgren K, Rylander E, Rådberg T et al. Colposcopic and histopathologic evaluation of women participating in population-based screening for human papillomavirus deoxyribonucleic acid persistence. Am J Obstet Gynecol 2005; 193 (3 Pt 1): 650-657

[61] Naucler P, Ryd W, Tornberg S et al. Human papillomavirus and Papanicolaou tests to screen for cervical cancer. N Engl J Med 2007; 357: 15891597 [Erratum in: N Engl] Med 2008; 359: 1637. Note: Johansson, Bo (added)]

[62] Balasubramanian A, Hughes ], Mao C et al. Evaluation of an ELISA for p 16INK4a as a screening test for cervical cancer. Cancer Epidemiol Biomarkers Prev 2009; 18: 3008-3017

[63] Hovland S, Arbyn M, Lie AK et al. A comprehensive evaluation of the accuracy of cervical pre-cancer detection methods in a high-risk area in East Congo. Br J Cancer 2010; 102: 957-965

[64] Depuydt CE, Makar AP, Ruymbeke MJ et al. BD-ProExC as adjunct molecular marker for improved detection of CIN2+ after HPV primary screening. Cancer Epidemiol Biomarkers Prev 2011; 20: 628-637
[65] Wu R, Belinson SE, Du H et al. Human papillomavirus messenger RNA assay for cervical cancer screening: the Shenzhen Cervical Cancer Screening Trial I. Int J Gynecol Cancer 2010; 20: 1411-1414

[66] Monsonego J, Hudgens MG, Zerat L et al. Evaluation of oncogenic human papillomavirus RNA and DNA tests with liquid-based cytology in primary cervical cancer screening: The FASE study. Int J Cancer 2011; 129: 691701

[67] Ratnam S, Coutlee F, Fontaine D et al. Aptima HPV E6/E7 mRNA test is as sensitive as hybrid capture 2 assay but more specific at detecting cervical precancer and cancer. J Clin Microbiol 2011; 49: 557-564

[68] Cuzick J, Cadman L, Mesher D et al. Comparing the performance of six human papillomavirus tests in a screening population. $\mathrm{Br}$ J Cancer 2013; 108: 908-913

[69] Nieves L, Enerson CL, Belinson S et al. Primary cervical cancer screening and triage using an mRNA human papillomavirus assay and visual inspection. Int J Gynecol Cancer 2013; 23: 513-518

[70] Ikenberg H, Bergeron C, Schmidt D et al. Screening for cervical cancer precursors with p 16/Ki-67 dual-stained cytology: Results of the PALMS study. J Natl Cancer Inst 2013; 105: 1550-1557

[71] Zhao FH, Jeronimo J, Qiao YL et al. An evaluation of novel, lower-cost molecular screening tests for human papillomavirus in rural China. Cancer Prev Res (Phila) 2013; 6: 938-948 


\section{Guideline Program}

\section{Editors}

Leading Professional Medical Associations

\section{Ty}

German Society of Gynecology and Obstetrics (Deutsche Gesellschaft für Gynäkologie und Geburtshilfe e. V. [DGGG])

Head Office of DGGG and Professional Societies Hausvogteiplatz 12, DE-10117 Berlin info@dggg.de

http://www.dggg.de/

\section{President of DGGG}

Prof. Dr. med. Anton Scharl

Direktor der Frauenkliniken

Klinikum St. Marien Amberg

Mariahilfbergweg 7, DE-92224 Amberg

Kliniken Nordoberpfalz AG

Söllnerstraße 16, DE-92637 Weiden

\section{DGGG Guidelines Representatives}

Prof. Dr. med. Matthias W. Beckmann Universitätsklinikum Erlangen, Frauenklinik Universitätsstraße 21-23, DE-91054 Erlangen

Prof. Dr. med. Erich-Franz Solomayer Universitätsklinikum des Saarlandes Geburtshilfe und Reproduktionsmedizin Kirrberger Straße, Gebäude 9, DE-66421 Homburg

\section{Guidelines Coordination}

Dr. med. Paul Gaß, Dr. med. Gregor Olmes, Christina Meixner Universitätsklinikum Erlangen, Frauenklinik Universitätsstraße 21-23, DE-91054 Erlangen fk-dggg-leitlinien@uk-erlangen.de http://www.dggg.de/leitlinienstellungnahmen

\section{OEGGG}

Austrian Society of Gynecology and Obstetrics (Österreichische Gesellschaft für Gynäkologie und Geburtshilfe [OEGGG])

Frankgasse 8, AT-1090 Wien

stephanie.leutgeb@oeggg.at

http://www.oeggg.at

\section{President of OEGGG}

Prof. Dr. med. Petra Kohlberger

Universitätsklinik für Frauenheilkunde Wien

Währinger Gürtel 18-20, AT-1090 Wien

\section{OEGGG Guidelines Representatives}

Prof. Dr. med. Karl Tamussino

Universitätsklinik für Frauenheilkunde und Geburtshilfe Graz Auenbruggerplatz 14, AT-8036 Graz

Prof. Dr. med. Hanns Helmer Universitätsklinik für Frauenheilkunde Wien Währinger Gürtel 18-20, AT-1090 Wien

\section{gynécologie
suisse}

Swiss Society of Gynecology and Obstetrics (Schweizerische Gesellschaft für Gynäkologie und Geburtshilfe [SGGG])

Gynécologie Suisse SGGG Altenbergstraße 29, Postfach 6, CH-3000 Bern 8 sekretariat@sggg.ch http://www.sggg.ch/

\section{President of SGGG}

Dr. med. David Ehm

FMH für Geburtshilfe und Gynäkologie Nägeligasse 13, CH-3011 Bern

\section{SGGG Guidelines Representatives}

Prof. Dr. med. Daniel Surbek Universitätsklinik für Frauenheilkunde Geburtshilfe und feto-maternale Medizin Inselspital Bern Effingerstraße 102, CH-3010 Bern

Prof. Dr. med. René Hornung Kantonsspital St. Gallen, Frauenklinik Rorschacher Straße 95, CH-9007 St. Gallen 